\title{
HUNTER-HERDERS IN THE LIMESTONE MASSIF OF ESTREMADURA: MIDDLE NEOLITHIC FAUNA FROM THE PENA D'ÁGUA ROCK- SHELTER (TORRES NOVAS, PORTUGAL)
}

\author{
FRANCISCO ROSA CORREIA ${ }^{(1)}$, SOFIA LUÍS ${ }^{(1)}$, PEDRO VALENTE FERNANDES ${ }^{(1),(2)}$, MARIA JOÃO \\ VALENTE $^{(1)} \&$ ANTÓNIO FAUSTINO CARVALHO ${ }^{(1)}$
}

\begin{abstract}
:
The Pena d'Água Rock-shelter (Torres Novas, Portugal) was excavated in 1992-2000, revealing a long stratigraphic and cultural sequence including Middle Neolithic occupations. A preliminary study on its fauna was published by Valente (1998) based on the 1992-1994 material, but the 1997-2000 campaigns remained unstudied. The aim of this study is to present the full fauna analysis of the layer $\mathrm{Db}$, dated from the earlier phases of that period.

Like other assemblages from the same time frame in the area, the fauna collection understudy is small. Its bones showed several surface and chemical alterations due to sediment pressure, exposure to fire and water percolation. Regarding the taxonomical abundances, most remains were classified as rabbit (Oryctolagus cuniculus) and sheep and/or goat (Ovis aries/Capra hircus). A few specimens of cervid, fox (Vulpes vulpes) and bird were also identified.

The other fauna assemblages from the region show either the prevalence of the caprine component (as in Pena d'Água) or a higher abundance of cervids. This trend may reflect a specialized animal exploitation and we propose that the Middle Neolithic human communities in the Limestone Massif had a subsistence strategy based on caprine exploration, supplemented by some cervid (red deer) hunting. These hunter-herders groups were probably highly mobile and may have practiced some kind of transhumance (or itinerant pastoralism), for which the details are still unknown.
\end{abstract}

Keywords: Middle Neolithic, Zooarchaeology, Pena d'Água Rock-shelter, Portuguese Estremadura, HunterHerders.

Resumo:

\begin{abstract}
Caçadores e pastores no maciço calcário estremenho: a fauna do Neolítico Médio do sítio do abrigo da Pena d'Água (Torres Novas, Portugal)

O abrigo da Pena d'Água (Torres Novas, Portugal) foi escavado entre 1992 e 2000, tendo revelado uma longa sequência estratigráfica e cultural, incluindo ocupações pertencentes ao Neolítico Médio. Uma análise preliminar foi publicada por Valente (1998), com base no material de 1992-1994; as campanhas de 1997-2000 permaneceram por estudar. O objetivo deste estudo passa por apresentar a análise zooarqueológica da fauna pertencente à camada $\mathrm{Db}$, atribuída à fase inicial do período.

Tal como outros contextos do mesmo período cronológico da região, a coleção faunística analisada é de pequenas dimensões. Os restos ósseos demonstram várias alterações superficiais e químicas, devido à pressão do sedimento, a exposição ao fogo e percolação da água. Em relação às abundâncias taxonómicas, a maioria dos restos foram classificados como pertencentes a coelho (Oryctolagus cuniculus) e ovelha e/ou cabra (Ovis aries/Capra hircus). Identificou-se ainda alguns restos como pertencentes a cervídeos, raposa (Vulpes vulpes) e ave.

Os outros contextos faunísticos da região revelam tanto a prevalência da componente caprina (como na Pena d’Água) ou uma maior abundancia de cervídeos. Esta tendência pode refletir uma exploração animal especializada e propomos que as comunidades humanas do Neolítico Médio no Maciço Calcário teriam uma estratégia de subsistência baseada na exploração caprina, completada pela caça de alguns cervídeos (veados). Estes grupos de caçadores e pastores seriam provavelmente bastante móveis e podem ter praticado algum tipo de transumância (ou pecuária itinerante), para a qual os detalhes são ainda desconhecidos.
\end{abstract}

Palavras-Chave: Neolítico Médio, Zooarqueologia, Abrigo da Pena d’Água, Estremadura Portuguesa, Caçadores e Pastores.

\section{INTRODUCTION}

It has been widely acknowledged the scarcity of empirical data from various domains regarding the middle phase(s) of the Neolithic in the Portuguese territory. Indeed, as evident in any syntheses published in the last quarter of a century (e.g., Jorge 1990; CARdoso 2007; CARVAlHo 2012), research has been focusing the «funerary side» of these societies, which in turn is due to an early attention - that goes back to the mid-19th century - paid to the numerous dolmens and cave sites known in the country. This research trend has hampered, among many other possible research possibilities, habitation sites to be discovered and adequately studied. As consequence, many aspects of the way of life of these Middle Neolithic societies - that could be obtained from the study of such type of archaeological evidence - are unknown

${ }^{(1)}$ Universidade do Algarve. Email de autor correspondente: franciscomrcorreia@gmail.com .

${ }^{(2)}$ Núcleo de Alunos de Arqueologia e Paleoecologia 
or remain only tentatively outlined. Stock-keeping and hunting strategies are just some of those topics.

In such research context, the aim of this paper is to present, and to discuss within a regional scale, the faunal remains exhumed during the excavation of layer $\mathrm{Db}$ from the rock-shelter site of Pena d'Água, located in the eastern rim of the
Limestone Massif of Estremadura (hereafter LME; Fig.1). These remains were preliminarily presented at the «VI Jornadas de Jóvenes en Investigación Arqueológica», that took place in Barcelona in 2013 (Luís et al. n.d.), whose proceedings were not published.

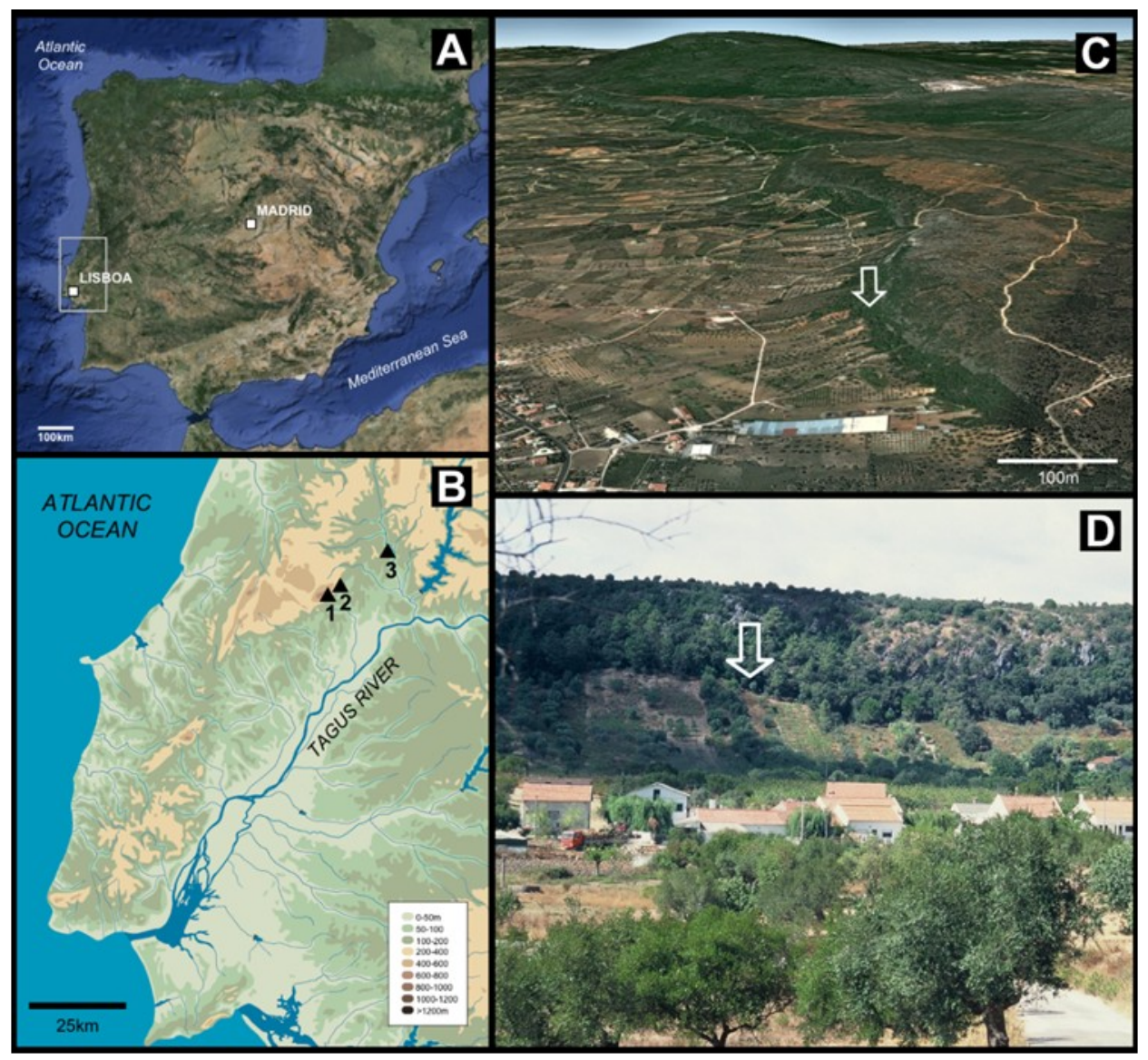

Fig. 1. A: Location of Estremadura and the Tagus Valley in western Iberia. B: Location of the mentioned archaeological sites (1 - Pena d'Água Rock-shelter; 2 - Costa do Pereiro; 3 - Cadaval Cave). C: A view of the Pena d'Água Rock-shelter (arrow) in Google ${ }^{\mathrm{TM}}$ Earth ${ }^{\circledR}$ showing the Arrife clearly separating the two contrasting landscapes, the limestone mountain (right) and the Tagus plain (left). D: Detail image of the Arrife showing the Pena d'Água Rock-shelter (arrow indicates the sector of the deposit where excavations took place).

Fig. 1. A: Localização da Estremadura e do Vale do Tejo no oeste da Península Ibérica. B: Localização dos sítios arqueológicos em estudo (1 - Abrigo da Pena d'Água; 2 - Costa do Pereiro; 3 - Gruta do Cadaval). C: Visualização do Abrigo da Pena d'Água (seta) em Google ${ }^{\mathrm{TM}}$ Earth ${ }^{\circledR}$ demonstrando o Arrife a separar claramente as duas paisagens contrastantes, a montanha calcária (direita) e a planície do Tejo (esquerda). D: Imagem detalhada do Arrife indicando o Abrigo da Pena d'Agua (a seta indica o sector do depósito onde os trabalhos arqueológicos decorreram).

\section{ARCHAEOLOGICAL CONTEXT}

Pena d'Água is the local site name for a sector of the ca. $60 \mathrm{~km}$-long fault escarpment that separates the LME from the Tagus river basin, in Portuguese Estremadura (district of Santarém, municipality of Torres Novas). The site name literally means "scarp of water" given the presence of a seasonal spring that, along with the "sheltereffect" and the ecotone conditions marked by two very contrasting areas (the LME and the Tagus Basin), may have attracted the human occupation.
This is a former rock-shelter, now collapsed, with an estimated length of $70 \mathrm{~m}$ and with a sedimentary deposit around $5 \mathrm{~m}$ thick in the tested sector.

Work at this archaeological site began in 1992 and was carried out in the framework of two successive research projects, «Carta Arqueológica do Parque Natural das Serras de Aire e dos Candeeiros» (directed by J. Zilhão in 1993-1995) and «Pré-História do Maciço Calcário das Serras de Aire e dos Candeeiros e Bacias de Drenagem Adjacentes» (directed by A.F. Carvalho in 1998- 
2001). During the excavations, it was possible to recognize six main stratigraphic layers (designated by A to F; Fig. 2) later detailed into nine cultural levels after the analysis of the vertical distribution of diagnostic material culture items (CARVALHO 1998, 2012). Occupations span from the Epipalaeolithic (layer F) to Iron Age and Roman (layer B), all with organic preservation (charcoal, fauna). Early to Late Neolithic occupations (layers Eb-bottom to B) constitute, however, the most important stratigraphic horizon. Its diachronic interpretation allows two main moments, or "stratigraphic blocks", to be identified within the Neolithic, whose separation occurs at the layer $\mathrm{Ea} /$ layer $\mathrm{Db}$ interface. This stratigraphic transition marks relevant changes at the palaeoeconomic and cultural levels (and also palaeoenvironmental?-see CARVALHO, n.d., 2015): material culture items witness a passage from very diversified decorated pottery productions in the older layers (Early Neolithic) to more homogeneous, undecorated potteries - of "dolmenic type" - in the subsequent, Middle and Late Neolithic occupations. Lithic assemblages, although characterized by the use of local raw material sources seem to reveal a major change regarding flint acquisition occurring at the same time, from the import of preformed cores along with finished bladelets in the Early Neolithic to the circulation of larger bladelets and blades in the following periods.

As mentioned above, the data presented here is related to the layer $\mathrm{Db}$, which corresponds to the early Middle Neolithic according to its material culture. A radiocarbon date of $5180 \pm 240 \mathrm{BP}$ (ICEN-1147), from a bulk sample of charcoal of wild olive tree (Olea europaea var. sylvestris), resulted, however, in a large standard deviation: $4522-3515 \mathrm{cal} \mathrm{BC}$, at $95.0 \%$ probability (using the IntCal13 calibration curve).

The faunal evidence presented in this paper was obtained in two different moments of the excavations carried out at the site: one, that took place in 1992-1994 in square units L-N/29-30, was published soon after by Valente (1998); another, corresponding to the 1997-2000 field seasons that focused on square units $\mathrm{I}-\mathrm{K} / 29-30$, was only briefly mentioned by Valente and Carvalho (2014). Now, we include the whole early Middle Neolithic faunal assemblage from the mentioned layer.

With the exception of very small collections from ill-defined archaeological contexts, faunal assemblages dated to this phase of the Neolithic are scarce in central-southern Portugal. Up to the moment, these have been identified only in three sites from the LME - Cadaval Cave (TOMÉ et al. 2013; Almeida et al. n.d.), Costa do Pereiro (CARvalho 2008) and Pena d'Água (this paper)in the shell-midden of Barrosinha (SOARES \& SILVA 2013) at the Comporta archaeological complex of the Sado estuary, and at the cave of Algarão da Goldra (STRAUS et al. 1992) in the Monte Figo Mountain North of Faro (for a synthesis, see VALENTE \& CARVALHO 2014).

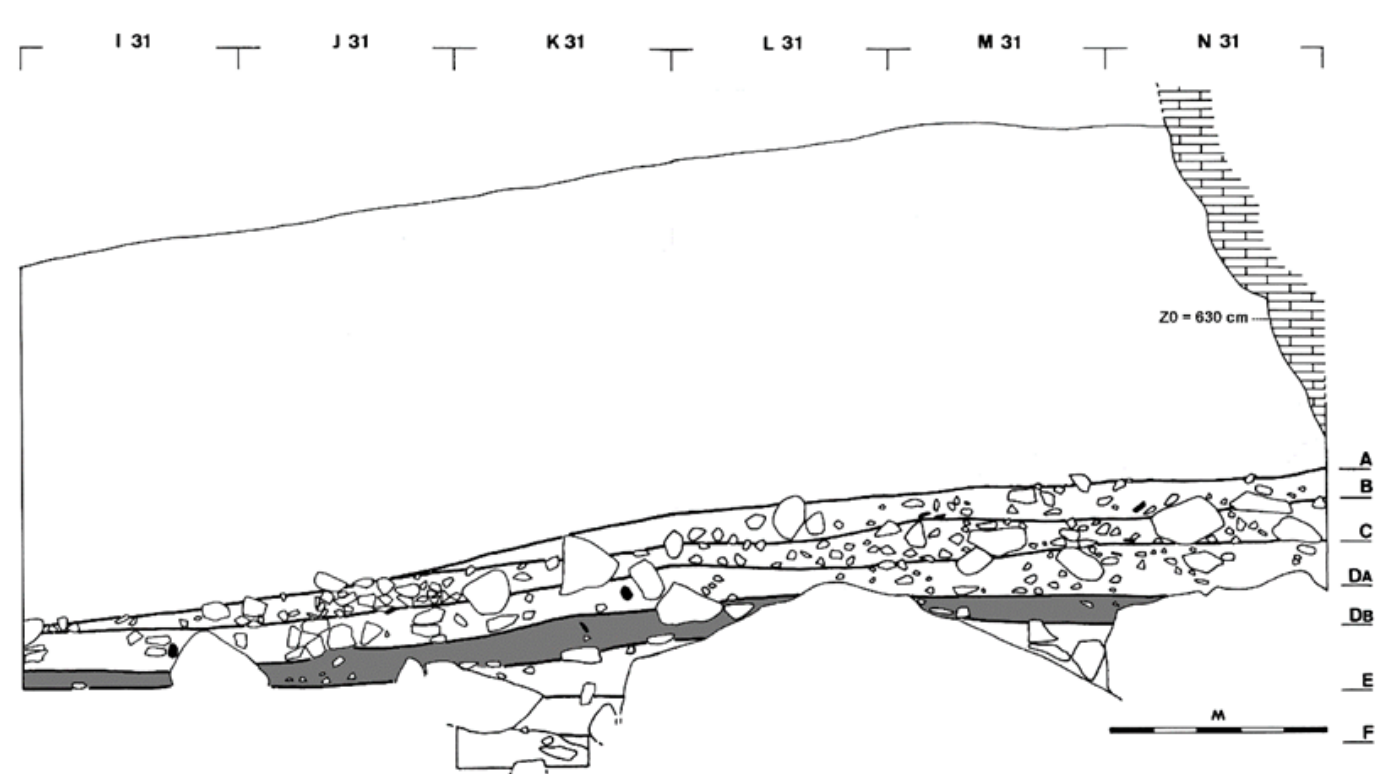

Fig. 2. Stratigraphy of the Pena d'Água Rock-shelter ("West Cut"), with indication of layer Db (greyish layer) within the sequence. $\mathrm{Z} 0=630 \mathrm{~cm}$ is the local datum used during excavations.

Fig. 2. Estratigrafia do Abrigo da Pena d'Água ("Corte Oeste"), com a indicação da camada Db (camada acinzentada) dentro da sequência. $Z 0=630 \mathrm{~cm}$ indica o "ponto zero" utilizado durante as escavações. 


\section{METHODOLOGY}

For the identification and analysis of these remains, we used essentially the reference collection stored at the Laboratory of Archaeology and Restoration of the University of Algarve. This collection was especially important in identifying Oryctolagus cuniculus (rabbit) and Ovis aries/Capra hircus (sheep and/or goat). The presence of Vulpes vulpes (fox) was confirmed through unofficial databases compiled by M. Stiner and J. P. Brugal.

The fauna material was examined and quantified following the common methodology in zooarchaeology (e.g. REITZ \& WINGS 2008). For quantification, we used the traditional quantifying units of Number of Identified Specimens (NISP) and Minimum Number of Individuals (MNI) (VALENTE 1997; LYMAN 2008). Long bones' diaphysis, ribs and vertebrae fragments are difficult to classify to the species level and for this group of unclassified remains, we created two general categories by animal size: remains that (by size and morphology) belonged Medium Size Animals (MSA) or to Small Size Animals (SSA) (Table 1). This determination can control some information loss by bad preservation of the bone, allowing us to observe patterns on the different sized animals (UERPMANN 1973; BRUGAL et al. 1994; VALENTE 1997).

Table 1. Size Classes

Tabela 1. Classes de Tamanho.

\begin{tabular}{|c|c|}
\hline Classes & Possible Taxa \\
\hline Big Size Animals (BSA) & $\begin{array}{c}\text { Equine, Aurochs, Ox, } \\
\text { Deer }\end{array}$ \\
\hline $\begin{array}{c}\text { Medium Size Animals } \\
\text { (MSA) }\end{array}$ & $\begin{array}{c}\text { Sheep, Goat, Pig, Boar, } \\
\text { Roe Deer, Ibex, Canids, } \\
\text { Lynx }\end{array}$ \\
\hline Small Size Animals (SSA) & Leporids, Birds \\
\hline
\end{tabular}

With the exception of a few bones or teeth, sheep and goats are very similar in size and morphology, which complicates their differentiation (e.g., BOESSNECK 1969; PRUMMEL \& FrISCH 1986; HELMER \& ROCHETEAU 1994; HATTING 1995; ZEDER \& LAPHAM 2010; ZEDER \& PILAAR 2010). In the present collection, due to its fragmentation and lack of anatomical elements that provide a clear distinction between these species, it was only possible to record the remains as belonging to the general category of Ovis/Capra.

To determine the age at death of mammals, there are two standard methods: (a) the state of fusion between the epiphysis and the diaphysis of long bones belonging to the appendicular skeleton; and (b) the eruption of permanent teeth and consequent replacement of milk teeth (e.g. SILVER 1969; PAYNE 1973; PÉREZ-RIPOLL 1999).

\section{RESULTS}

In layer $\mathrm{Db}, 260$ remains were collected and analyzed and, of these, 163 remains were determined (=NISP; Table 2).

Taxonomically, 133 remains were identified as belonging to Oryctolagus cuniculus, the most abundant species in the assemblage. We have identified 24 remains belonging to caprines, most probably Ovis aries and/or Capra hircus. It was impossible to take any reliable measurements, but we have no evidences that support the existence of Capra pyrenaica. Also to be noticed that, during this timeframe in the Limestone Massif, we have no indication of the presence this species (see data by archaeological site in VALENTE \& CARVALHO 2014). We could also classify two remains belonging to Vulpes vulpes and three belonging to uncertain cervid, possibly Cervus elaphus (red deer). It was also identified one remain belonging to an unclassified bird. In addition to the above, we have classified nine remains to SSA and 40 to MSA. Finally, 48 remains were considered non-identified (around $90 \%$ belong to specimens with less than $2 \mathrm{~cm})$.

In the absence of any remains belonging to immature animals (unfused bones or deciduous teeth) only one class of animals (adults) was determined. Further data on age was impossible given the small sample and the level of fragmentation of the collection.

The material collected showed intense fragmentation, without the record of any complete elements with the exception of two leporids phalanges I.

Regarding post-mortem evidences presumably caused by humans, during this study we have only detected traces of fire action in some fauna remains.

Taphonomic indicators revealed 77 charred remains (all of black coloration). Most belong to rabbit, but there are several remains of MSA (including two caprid remains) that also show burning evidences. No cut or blow marks were identified.

\section{DATA INTERPRETATION}

Due to the small number of faunal remains from layer $\mathrm{Db}$ and their high level of fragmentation, the conclusions we can draw are limited.

Indeed, the overwhelming majority of the faunal materials from Pena d'Água are in very bad preservation conditions. The main causes of this limitation are of taphonomical nature, namely physical and chemical alterations. These alterations are likely due to post-depositional processes related to hydrological forces and chemical action of water on the faunal remains (VALENTE 1998); however, we should not exclude that some part of 
Table 2. Quantitative data of the fauna remains (total number of identified specimens) in layer Db.

Tabela 2. Dados quantitativos dos restos faunísticos (número de restos determinados) na camada $\mathrm{Db}$.

\begin{tabular}{|c|c|c|c|c|c|c|c|c|}
\hline & OC & C & CE & VV & Bird & MSA & SSA & IND \\
\hline \multicolumn{9}{|l|}{ CRANIAL } \\
\hline Horn & & & & & & 3 & & \\
\hline Cranium & 1 & & & & & & & \\
\hline Upper teeth & & & & 2 & & & & \\
\hline Mandible & 2 & 2 & & & & & & \\
\hline Lower teeth & & 3 & & & & & & \\
\hline Other teeth & 2 & 12 & 3 & & & 6 & & \\
\hline \multicolumn{9}{|l|}{ AXIAL } \\
\hline Vertebra & & & & & & 1 & & \\
\hline Rib & 3 & 1 & & & & 1 & & \\
\hline \multicolumn{9}{|c|}{$\begin{array}{l}\text { ANTERIOR } \\
\text { APPENDICULAR }\end{array}$} \\
\hline Scapula & 1 & & & & & & & \\
\hline Humerus & 3 & & & & & & & \\
\hline Ulna & 1 & & & & & & & \\
\hline \multicolumn{9}{|c|}{$\begin{array}{l}\text { POSTERIOR } \\
\text { APPENDICULAR }\end{array}$} \\
\hline Innominate & 6 & & & & & & & \\
\hline Femur & 1 & & & & & & & \\
\hline Tibia & 10 & & & & & & & \\
\hline Astragalus & & 1 & & & & & & \\
\hline Calcaneum & 5 & & & & & & & \\
\hline Metatarsal & 1 & & & & & & & \\
\hline \multicolumn{9}{|c|}{$\begin{array}{l}\text { OTHER } \\
\text { APENDICULAR }\end{array}$} \\
\hline Metapode & 4 & 1 & & & & & & \\
\hline Phalanx & 2 & & & & 1 & & & \\
\hline \multicolumn{9}{|l|}{ OTHER } \\
\hline Long bones & 76 & 4 & & & & 11 & 1 & 1 \\
\hline Other bones & 15 & & & & & 18 & 8 & 47 \\
\hline $\begin{array}{l}\text { TOTAL } \\
\text { REMAINS }\end{array}$ & 133 & 24 & 3 & 2 & 1 & 40 & 9 & 48 \\
\hline MNI & 3 & 1 & 1 & 1 & 1 & & & \\
\hline
\end{tabular}

Taxa = OC: Oryctolagus cuniculus; C: Caprines (no species classification; probably Ovis aries and/or Capra hircus); CE: Cervid; VV: Vulpes vulpes. MSA (Medium Size Animal); SSA (Small Size Animal); MNI (Minimum Number of Individuals).

the breakage was caused by humans during the processing of the animal carcasses as food.

As mentioned above, the quantification of the analyzed assemblage is of great importance. This stands out especially in the case of NISP-MNI comparison. In total, we determined the presence of at least seven individuals: one unclassified bird and one cervid, one fox, one caprid (sheep or goat), and three rabbits (by means of three distal parts of the right part of the pelvis). These results indicate a higher loss of cervid, fox and bird remains (low
NISP, low MNI) when comparing with rabbit and caprids (higher NISP, low MNI). The possible reasons for these differences are:

(a) Differential transportation. This might be the case of cervids and, perhaps, fox. For these animals only some part of the carcass was transported to the site.

(b) Differential preservation/facturing. This mainly applies to caprids and leporids, which may show different processing tech- 
niques, evolving higher or lower degree of fracturing, respectively. On this regard, the representativeness of taxonomically unclassified bony elements could also be taken into account: the MSA are much more represented than SSA, which attest that the middle sized animals had indeed a higher degree of fracturing (perhaps caprids, with bone breakage caused by human processing) than smaller animals (leporids, processed without intentional breakage of the bones).

Following this line of thought (i.e., rabbits with lower fracturing and higher degree of preservation) we should discuss the nature of the rabbits' presence in the archaeological context. Did rabbits play an important role in the Middle Neolithic subsistence strategy at Pena d'Água? Or is their presence of intrusive nature (rabbits being burrowing animals)?

If the latter, we would expect a higher number of complete elements, eventually with some anatomical connection, something that was not recorded during the excavation. In addition, a high number of distal and proximal ends of long bones (humerus and tibia) were found, together with some diaphysis fragments. This pattern shows that these bones could have been intentionally broken for bone marrow extraction (e.g., HOCKETT 1995). Also, the number of burned rabbit remains is quite high, and they show similar features to the burned remains of other animals. All these evidences led us to conclude that the presence of rabbit does not result from intrusions, but that rabbit was indeed part of the human diet in the Middle Neolithic of Pena d'Água.

As in the case of the rabbit, fox remains may also raise doubts as to the origins of their presence in the context understudy. If its presence is the result of intrusions (i.e., the animal doing a den and then perishing in the site), again it would be expectable a higher number of anatomical elements (only two teeth were found). Could foxes have been used for their fur by the Neolithic group that camp here? Could their teeth have been used as trophies? Until further evidences are recovered we cannot advance a definite answer.

The presence of (red) deer in this Neolithic context seems to match the idea of hunting, even if in such reduced presence of remains (only three teeth fragments). Like we propose above, regarding this animal (and fox) there might have been a partial transportation of their remains (or partial carcass?) to the site itself, a pattern not unusual for hunting prey.

On the other hand, the sure presence of goat and/or sheep substantiates an already wellestablished herding practice by the Middle Neolithic communities of the current Portuguese Estremadura. To be noticed that these are highly mobile species unlike other domesticated animals, such as cows or pigs, which tend to adapt better to enclosed confinement.

In sum, we suggest, with some reservations given the small collection, that during the Middle Neolithic the rock-shelter of Pena d'Água may have been a hunting and shepherd temporary camp. It can either be a satellite site of more permanent settlements located in the Tagus Valley-these groups may have been, in this possibility, "hunterherders", adopting a highly mobile pastoralism - or a small-scale agriculture may have also been practiced in the site's vicinities. With the evidence available for the Limestone Massif of Estremadura, which is very scarce in this domain (see below), it is problematic to opt for one or another of the aforementioned hypotheses.

\section{ZOOARCHEOLOGICAL INTERPRETATION IN THE CONTEXT OF THE LIMESTONE MASSIF OF ESTREMADURA}

In the Limestone Massif of Estremadura, faunal assemblages dating to the Middle Neolithic are limited to three-all small collections with poorly preserved materials due to high fragmentation and mechanical/chemical alterations, which prevents full conclusions. Nonetheless, these sites exist, thus allowing some comparison with layer Db from Pena d'Água: Costa do Pereiro campsite (CARVAlho 2008; VAlente \& CARVAlHo 2014; work in progress), Cadaval Cave (TOMÉ et al. 2013; ALMEIDA et al. n.d.; work in progress) and the upper occupations of Pena d'Água, recorded in layers Da and C (VALENTE 1998) (Fig. 2)

Despite the above-mentioned limitations, a notable variety of faunal taxa at these sites is evident (Table 3). They include both wild (Cervus elaphus and Capreolus capreolus) and domestic species (Ovis aries/Capra hircus and Bos taurus). Some remains, namely swine (Sus sp.) and a small amount of bovines (Bos sp.), could not be assigned to a species and their wild/domestic status remains unsure. In fact, the exact time in which swines became domesticated in SW Iberia is still an open question (e.g., AlBarella et al. 2005; VALENTE \& CARVALHO 2014). This taxonomic variety is testimony to a mixed subsistence strategy in which hunting would represent an important complement to stock-keeping practices.

The referred sites are characterized by a relative abundance of caprines and cervids, in terms of NISP. As pointed out elsewhere (VALENTE \& CARVALHO 2014), in the Early-to-Middle Neolithic transition, we may be witnessing a change in the animal exploitation strategies, featuring a dramatic reduction of swine and bovines remains and a specialization in the hunting of cervids (mostly red deer) and herding of sheep and/or goats. Indeed, other medium and large-sized mammals, like swine and bovines, are completely absent from any of the 
Table 3. Faunal abundance (total number of identified specimens) in the Middle Neolithic of the Limestone Massif of Estremadura. Tabela 3. Abundancia faunística (número de restos determinados) no Neolítico Médio do Maciço Calcário Estremenho.

\begin{tabular}{|l|l|l|l|l|l|l|l|l|l|l|l|l|l|}
\hline Site & Wild & Domestic & Ind. & CE & CC & S & B & BT & C & OA & CH & Total & Ref. \\
\hline $\begin{array}{l}\text { Cadaval Cave, } \\
\text { layer C }\end{array}$ & $\begin{array}{l}4 \\
(7 \%)\end{array}$ & $\begin{array}{l}45 \\
(79 \%)\end{array}$ & $\begin{array}{l}8 \\
(14 \%)\end{array}$ & 3 & 1 & 8 & - & 4 & 29 & 7 & 5 & 57 & {$[1]$} \\
\hline $\begin{array}{l}\text { Cadaval Cave, } \\
\text { layer D }\end{array}$ & $\begin{array}{l}4 \\
(11 \%)\end{array}$ & $\begin{array}{l}29 \\
(76 \%)\end{array}$ & $\begin{array}{l}5 \\
(13 \%)\end{array}$ & 3 & 1 & 5 & - & 2 & 17 & 2 & 8 & 38 \\
\hline $\begin{array}{l}\text { Pena d'Água, } \\
\text { layer C }\end{array}$ & $\begin{array}{l}18 \\
(39 \%)\end{array}$ & $\begin{array}{l}28 \\
(61 \%)\end{array}$ & - & 18 & - & - & - & - & 24 & - & 4 & 46 \\
\hline $\begin{array}{l}\text { Pena d'Água, } \\
\text { layer Da }\end{array}$ & $\begin{array}{l}1 \\
(10 \%)\end{array}$ & $\begin{array}{l}9 \\
(90 \%)\end{array}$ & - & 1 & - & - & - & - & 9 & - & - & 10 \\
\hline $\begin{array}{l}\text { Pena d'Água, } \\
\text { layer Db }\end{array}$ & $\begin{array}{l}3 \\
(11 \%)\end{array}$ & $\begin{array}{l}24 \\
(89 \%)\end{array}$ & - & 3 & - & - & - & - & 24 & - & - & 27 \\
\hline $\begin{array}{l}\text { Costa do } \\
\text { Pereiro }\end{array}$ & $\begin{array}{l}47 \\
(65 \%)\end{array}$ & $\begin{array}{l}9 \\
(13 \%)\end{array}$ & $\begin{array}{l}16 \\
(22 \%)\end{array}$ & 47 & - & 13 & 3 & - & 7 & - & 2 & 72 \\
\hline
\end{tabular}

Taxa (birds, leporidae and carnivores not included) = CE: Cervus elaphus (red deer); CC: Capreolus capreolus (roe deer); S: Swine (no species classification; either pig or wild boar); B: Bovines (no species classification; either cattle or aurochs); BT: Bos taurus (cattle); C: Caprines (no species classification; probably OA and/or $\mathrm{CH}$ ); OA: Ovis aries (sheep); $\mathrm{CH}$ : Capra hircus (domestic goat).

References: [1] Tomé et al. (2013); [2] Almeida et al. (s.d.) (work in progress); [3] Valente (1998); [4] Valente (1998) and this study; [5] Carvalho (2008) and Valente and Carvalho (2014) (work in progress).

Pena d'Água's Middle Neolithic layers, whereas roe deer is recorded at Cadaval only. Small-sized species - such as leporids, carnivores or birds - are not represented in Table 3 since their origin, human or natural, could not be verified; however, some role in human subsistence should not be ruled out.

Also, if quantitative comparisons between sites are made at the wild versus domestic level (Table 3), the following can be noticed: wild species predominate only at Costa do Pereiro $(65 \%$ NISP) and the only other context where these still bear some significance percentage is at layer $\mathrm{C}$ from Pena d'Água (39\%); in the remaining contexts wild species are restricted to around $10 \%$, whereas domesticates vary between $80-90 \%$. This trend reveals the overall importance of caprines in Middle Neolithic stock-keeping strategies.

Two of the assemblages deserve further comments: Cadaval Cave and layer C of Pena d'Água. Regarding the former, its role in the human settlement system remains to be fully understood. It is beyond doubt that it included a funerary occupation (several publications detailed descriptions of funerary practices and structures; e.g., OOSTERBEEK 1985). However, the number of faunal remains exceeds what is recognized in other burialcaves within the region, where animal remains are mostly represented by bone tools. Thanks to the zooarchaeological work being carried by Almeida et al. (n.d.), it is now possible to envisage a mixed occupation of the site with human burials and temporary residential occupations taking place in sequence. A parallel situation, not far from Cadaval, would be the Early Neolithic of the Caldeirão Cave (ZILHÃo 1992). As for Layer C at Pena d'Água, it was assigned to a transitional phase between the
Middle and the Late Neolithic (CARVALHO 1998) but a continuity in subsistence seems clear. However, the unbalanced relation between wild and domestic species is attenuated, with $40 \%$ and $60 \%$ of NISP, respectively.

As mentioned before, the only testimony to an opposite pattern is Costa do Pereiro, in which wild specimens predominate. This could mean some form of specialisation in the hunting of cervids by the human group that settled there. However, it must be stressed that the inventory presented in Table 3 is preliminary (work is still in progress) and, most importantly, that the total number of NISP may be disaggregated if the two radiocarbon dates from top of layer $1 \mathrm{~b}$ (CARVALHO 2008) are confirmed to be two latent Neolithic occupations. This would raise some questions: What faunal spectra will correspond to each occupation? Will we observe the same trend of decreasing representativeness of (the already few) swine and bovines? Only vertical projections of faunal remains (in course) may be able to answer such conjectures.

Regarding Middle Neolithic pastoralism, it is also important to mention the recent results from Bom Santo Cave, located in the Montejunto Mountain, north of Lisbon. Strontium and oxygen isotopes from sheep/goats indicated that two out of the three analysed specimens are not local, in line with similar results obtained from human remains. The interpretation put forward by Carvalho et al. (2015) is that of a mobile population practicing some form of itinerant pastoralism. If this model is confirmed by future research - either based on zooarchaeological studies or isotope analyses - it may be a depiction of similar herding practices taking place in the LME during the Middle Neolithic. 
In sum, it is our understanding that the existing data for Middle Neolithic in the area understudy supports the idea of a subsistence strategy based on caprine exploration, supplemented by some cervid hunting (mostly red deer). On this regard, we should not overlook the possibility of these hunter-herders groups having some kind of transhumant behavior: the LME would be part of their seasonal routes in which context the temporary occupation of the above sites would have taken place. The current state of research does not allow us to evaluate the role played by agriculture in this site, nor to identity the origin of these groups. However, we can suggest that they come from lower regions (e.g. Tagus Valley), where bigger, more permanent, dwellings - where a full farming economy could be establish-may have existed and be found in the future.

\section{REFERENCES}

Albarella, U.; Davis, S.J.,;Detry, C. \& Rowley Conwy, P. 2005. Pigs of the "Far West": the biometry of Sus from archaeological sites in Portugal. Anthropozoologica, 40: 27-54.

Almeida, N.; SAladié, P. \& OosterbeeK, L. n.d. Zooarqueologia e Tafonomia da Gruta da Nossa Senhora das Lapas e Gruta do Cadaval (Alto Ribatejo, Portugal Central). Actas do $5^{\circ}$ Congresso do Neolítico Peninsular, Lisboa: Universidade de Lisboa.

BoEsSNECK, J. 1969. Osteological Differences between Sheep (Ovis Aries Linné) and Goat (Capra Hircus Linné). In: Brothwell, D.R. \& Higgs, E.S. (Eds.), Science in Archaeology: A Comprehensive Survey of Progress and Research, London: 331-58.

Brugal, J.P.; DAVID, F. \& FARIZY, C. 1994. Quatification d'un assemblage osseux: paramètres et tableaux. Artefacts, 9: 143-153.

Cardoso, J.L. 2007. Pré-História de Portugal. Lisboa, Universidade Aberta.

Carvalho, A.F. 1998. O Abrigo da Pena d'Água (Rexaldia, Torres Novas): resultados dos trabalhos de 1992-1997. Revista Portuguesa de Arqueologia, 1(2): 39-72.

Carvalho, A.F. 2008. A neolitização do Portugal meridional. Os exemplos do Maciço Calcário Estremenho e do Algarve ocidental. Faro, Universidade do Algarve (Promontoria Monográfica $\mathrm{N}^{\mathrm{o}} 12$ ).

Carvalho, A.F. 2012. Portugal. In: RoJo, M.; Garrido, R. \& GARCíA, Í. (Coord.), El Neolítico en la Península Ibérica y su contexto europeo, Madrid, Cátedra: 175212.

Carvalho, A.F. 2014. Bom Santo Cave (Lisbon) and the Middle Neolithic Societies of Southern Portugal. Faro: Universidade do Algarve (Promontoria Monográfica $\mathrm{N}^{\circ} 17$.

CARvalho, A.F. 2015. A two-stage economic succession at the inception of farming in central Portugal. Preliminary examination of possible causes and consequences. Vegueta, 15: 89-109.

Carvalho, A.F., n.d. The Pena d'Água Rock-shelter (Torres Novas, Portugal): two distinct life ways within a Neolithic sequence. In: JUAN-CABANILLES, J. (Ed.), Homenaje a Bernart Martí. Valencia: Museo de Prehistòria de Valencia: in press

Carvalho, A.F.; Alves-Cardoso, F; Gonchlves, D.; Granja, R.; CARDOSO, J.L.; DEAN, R.M.; GibALA, J.F.; MASUCCI, M.A., ARROYO-PARdo, E.; Fernández-Domínguez, E.; Petchey, F.; Price, T.D.; Mateus, J.E.; Queiroz, P.F.; Callapez, P.; Pimenta, C. \& Regala, F.T. 2015. The Bom Santo Cave (Lisbon, Portugal): Catchment, Diet, and Patterns of Mobility of a Middle Neolithic Population. European Journal of Archaeology, doi:10.1179/1461957115y.0000000014

HATting, T. 1995. Sex-related characters in the pelvic bone of domestic sheep (Ovis aries L.). Archaeofauna, $\mathrm{n}^{\circ} 4: 71-76$

Helmer, D. \& Rocheteau, M. 1994. Fiches Atlas du squelette appendiculaire des principaux genres holocènes de petits ruminants du Nord de la Méditerranée et du Proche-Orient (Capra, Ovis, Rupicapra, Capreolus, Gazella). Première partie: La scapula et l'humérus. Fiches d'Ostéologie Animale pour l'Archéologie, Série B: Mammifères, $\mathrm{N}^{\circ} 4$.

HocketT, B.S. 1995. Comparasion of Leporid Bones in Raptor Pellets, Raptor Nests, and Archaeological Sites in the Great Basin. North American Archaeologist, 16 ( $\left.\mathrm{n}^{\circ} 3\right)$ : 223-238.

JORGE, S.O. 1990. A consolidação do sistema agro-pastoril. In: ALARCÃO, J., (Coord.), Nova História de Portugal. Portugal: das origens à romanização, Lisboa, Presença: 102-162.

Lyman, R. L. 2008. Quantitative Paleozoology. Cambridge, University Press.

Luís, S.; Correia, F.R. \& Fernandes, P.V. n.d. Middle Neolithic Zooarchaeology at the Pena d'Água Rock -shelter (Portuguese Estremadura). VI Jornadas de Jóvenes en Investigación Arqueológica. Barcelona: Universitat de Barcelona.

Oosterbeek, L. 1985. A fácies megalítica da Gruta do Cadaval (Tomar). I Reunião do Quaternário Ibérico, vol. II, Lisboa: Grupo de Trabalho Português de Estudo do Quaternário / Asociación Española para el Estudio del Cuaternário: 147-160.

PAYNE, S. 1973. Kill-off patterns in sheep and goats: the mandibles from Asvan Kale. Anatolian Studies, 23 281-303.

PÉREZ-RIPOLL, M. 1999. La explotación ganadera durante el tercer milénio en la Peninsula Iberica. Actes del II congrés de Neolitic a la Peninsula Ibérica, Saguntum Extra, 2: 95-106.

Prummel, W. \& Frisch, H.-J. 1986. A Guide for the Distinction of Species, Sex and Body Side in Bones of Sheep and Goat. Journal of Archaeology Science, 13: $567-77$.

ReITZ, E.J. \& WING, E.S. 2008. Zooarchaeology. Cambridge, University Press, Second Edition.

SILVER, I.A. 1969. The ageing of domestic animals. In: Brothwell, D. \& Higgs, E.S., (Eds.), Science in Archaeology. London, Thames and Hudson: 283-302.

SoARES, J. \& SilvA, C.T. 2013. Economia agro-marítima na Pré-História do Estuário do Sado. Novos dados sobre 
Hunter-herders in the limestone massif of Estremadura: Middle Neolithic fauna from the Pena d'Água rock-shelter

(Torres Novas, Portugal)

o Neolítico da Comporta. In: SOARES, J. (Ed.), PréHistória das zonas húmidas. Paisagens de sal. Setúbal, Museu de Arqueologia e Etnografia do Distrito de Setúbal (Setúbal Arqueológica; 14):145-170.

Straus, L.G.; Altuna, J.; Ford, D.; Marambat, L.; RHINE, J.S.; SCHWARCZ, J.-H.P. \& VERNET, J.-L. 1992. Early farming in the Algarve (Southern Portugal): a preliminary view from two cave excavations near Faro. Trabalhos de Antropologia e Etnologia, XXXII: 141-161.

Tomé, T.; Almeida, N.; Silva, A.M.; Saladié, P. \& OoSTERBEEK, L. 2013. Uma perspectiva osteoarqueológica sobre duas grutas neolíticas do Vale do Nabão (Alto Ribatejo, Portugal central). In: CruZ, A.R.; GraÇA, A.; OOSTERbeeK, L. \& Rosina, P., (Eds.), 1. ${ }^{\circ}$ Congresso de Arqueologia do Alto Ribatejo. Homenagem a José da Silva Gomes. Tomar, Centro Europeu de Investigação da Pré-História do Alto Ribatejo (Arkeos; 34): 131-142.

UERPMANN, H.P. 1973. Animal bones and economic archaeology: a critical study of "osteo-archaeological" method. World Archaeology, 4: 307-322.
VALENTE, M.J. 1997. A quantificação faunística: principais unidades, alguns parâmetros, regras e problemas. Estudos do Quaternário, 1: 83-96.

VALENTE, M.J. 1998. Análise preliminar da fauna mamalógica do Abrigo da Pena d'Água (Torres Novas): campanhas de 1992-1994. Revista Portuguesa de Arqueologia, 1 (n²): 85-96.

VAlente, M.J. \& CARVAlHo, A.F. 2014. Zooarchaeology in the Neolithic and Chalcolithic of Southern Portugal. Environmental Archaeology, 9 (nº3): 226-240.

ZEDER, M.A. \& LAPHAM, H.A. 2010. Assessing the reliability of criteria used to identify postcranial bones in sheep, Ovis, and goats, Capra. Journal of Archaeological Science, 37: 2887-2905.

Zeder, M.A. \& PILAAR, S.E. 2010. Assessing the realiability of criteria used to identify mandibles and mandibular teeth in sheep, Ovis, and goats, Capra. Journal of Archaeological Science, 37: 225-242.

ZILHÃo, J. 1992. Gruta do Caldeirão. O Neolítico antigo. Trabalhos de Arqueologia, nº, Lisboa: Instituto Português do Património Arquitectónico e Arqueológico. 